\title{
CalCium OXALATE CRYSTALS IN SOME SPECIES OF THE Tribe Cardueae (Asteraceae)
}

\author{
Ciler Kartal \\ Department of Biology, Faculty of Science, Trakya University, Edirne, Turkey \\ Corresponding author: cilermeric@yahoo.com
}

\begin{abstract}
Calcium oxalate (CaOx) crystals in the tissues and organs of 18 species that belong to tribe Cardueae (Asteraceae), Arctium minus, Carduus candicans, C. nutans, C. pycnocephalus, Cirsium arvense, C. creticum, C. vulgare, Jurinea consanguinea, Silybum marianum, Tyrimnus leucographus, and Xeranthemum annuиm within the subtribe Carduinae and Carthamus dentatus, C. lanatus, Centaurea cyanus, C. diffusa, C. iberica, C. salonitana, and C. solstitialis within the subtribe Centaureinae, were investigated, and their morphologies and distribution were determined using light microscopy. Two morphological types of crystals, styloids and prismatics, were the most commonly found crystals in the species examined. Raphides were only observed in the stem cortex and pith parenchyma cells of S. marianum, while druses were only viewed in the stem pith cells of $C$. pycnocephalus. Styloids were observed (if present) in the leaf, corolla, anther, filament, and style tissues. Prismatic crystals were common in almost all ovaries of the species investigated except Xeranthemит апnиит which was found to include styloids in its ovary cells. Prismatics, styloids, raphides, and druses were present in the stems of the species. It is considered that crystal formation within the cell is under genetic control. Thus the type, and presence or absence of crystals may be represented as a taxonomic character. In conclusion, it is suggested that the type and location of $\mathrm{CaOx}$ crystals in the Cardueae constitute a diagnostic character and they may have taxonomic significance in this tribe.
\end{abstract}

Keywords: Asteraceae, Cardueae, calcium oxalate crystals, prismatics, styloids

Resumen: Se analizaron los cristales de oxalato de calcio $(\mathrm{CaOx})$ en los tejidos y órganos de 18 especies que pertenecen a la tribu Cardueae (Asteraceae), Arctium minus, Carduus candicans, C. nutans, C. pycnocephalus, Cirsium arvense, C. creticum, C. vulgare, Jurinea consanguinea, Silybum marianum, Tyrimnus leucographus, y Xeranthemum annuum dentro de la subtribu Carduinae y Carthamus dentatus, C. lanatus, Centaurea cyanus, $C$. diffusa, C. iberica, C. salonitana, y $C$. solstitialis dentro de la subtribu Centaureinae. Se determinó su morfologías y distribución mediante microscopía de luz. Los tipos morfológicos de cristales más comúnmente encontrados en las especies examinadas fueron los estiloides y prismáticos. Los rafidios solamente se observaron en las células de la corteza del tallo y de la médula del parénquima de S. marianum, mientras que las drusas solamente se observaron en las células madre de médula de C. pycnocephalus. Los estiloides se observaron (si estaban presentes) en los tejidos de la hoja, la corola, anteras, filamentos, y el estilo. Los cristales prismáticos fueron comunes en los ovarios de casi todas las especies investigadas excepto en Xeranthemuт аппиит en donde se encontraron estiloides en las células de ovario. Los prismáticos, estiloides, rafidios y drusas estuvieron presentes en los tallos de todas las especies. Se considera que la formación de cristales dentro de la célula está bajo control genético. Así, el tipo y la presencia o ausencia de cristales pueden considerarse como un carácter taxonómico. En conclusión, se sugiere que el tipo y la ubicación de los cristales $\mathrm{CaOx}$ en el Cardueae constituye un carácter de diagnóstico y pueden tener importancia taxonómica en esta tribu.

Palabras clave: Asteraceae, Cardueae, cristales de oxalato de calcio, prismáticos, estiloides

$\mathrm{C}$ alcium oxalate $(\mathrm{CaOx})$ crystals are widely distributed in plants and are found in over 215 plant families (Franceschi and Horner, 1980; Molano-Flores, 2001). They occur in different plant tissues, including the leaves (Lersten and Horner, 2000; Horner et al., 2012), stems (Meric, 2008, 2009a), roots (Kausch and Horner, 1984; Dane et al., 2000;
Horner et al., 2000) and seeds (Ilarslan et al., 2001). The $\mathrm{CaOx}$ crystals also occur in floral organs, including the ovaries (Dormer, 1961, 1962; Tilton and Horner, 1980; Meric, 2008, 2009a, b), anthers (Horner, 1977; Meric, 2009a, b), and petals (Meric, 2008, 2009b). The only place where crystals have not been observed is the pollen (Tilton and 
Horner, 1980). However, their functional significance remains unclear, although various functions have been attributed to them. These functions include calcium regulation in plant cells (Franceschi, 1989; Kostman and Franceschi, 2000; Volk et al., 2002), protection against herbivory (Molano-Flores, 2001), detoxification of heavy metals or oxalic acid (Franceschi and Nakata, 2005), tissue strength, and light gathering and reflection (Franceschi and Horner, 1980; Kuo-Huang et al., 2007).

The shapes of $\mathrm{CaOx}$ crystals vary and they are commonly described as raphides, druses, styloids, prisms, and crystal sand (Franceschi and Horner, 1980; Franceschi and Nakata, 2005). The distribution and shapes of these crystals have been used as taxonomic characters for a number of plant families (Prychid and Rudall, 1999; Lersten and Horner, 2000, Horner et al., 2012). Prychid and Rudall (1999) reported that there are three main types of $\mathrm{CaOx}$ crystals in monocotyledons: raphides, styloids, and druses. Styloids are characteristic of some families of Asparagales, while they are entirely absent in Iridaceae. Druses are relatively rare in monocotyledons compared to dicotyledons (Prychid and Rudall, 1999). Lersten and Horner (2000) determined six major $\mathrm{CaOx}$ crystal macropatterns in the genus Prunus, and they showed that the types and distribution of $\mathrm{CaOx}$ crystals represent a systematically significant feature among the five subgenera.

Asteraceae Bercht. \& J. Presl. is one of the largest families in the plant kingdom, with approximately 23,000 species. It is widespread with many genera and species, and it includes many crops and ornamental plants (Bremer, 1994). The tribe Cardueae Cass. is composed of about 74 genera and 2,500 species. It is divided into five subtribes: Echinopinae, Carlininae, Carduinae Centaureinae, and Cardopatiinae (Susanna et al., 2006). However, taxonomic problems of this tribe have not been solved yet. The tribe is distributed mainly in Eurasia, chiefly in the Mediterranean and Southwest and Central Asia. The species are generally robust and are often spiny herbs (Davis, 1975).

The $\mathrm{CaOx}$ crystals in Asteraceae were shown by some previous studies (Dormer, 1961, 1962; Horner, 1977; Meric and Dane, 2004; Meric, 2008, 2009a, b). For crystals, the ovaries of some taxa of the tribe Cardueae were examined by Dormer $(1961,1962)$. The author determined prismatic crystals in different lengths in the parenchymatous cells of the ovaries (Dormer, 1961). Meric and Dane (2004) examined $\mathrm{CaOx}$ crystals in the floral organs of Helianthus $\mathrm{L}$. species (Heliantheae). Meric (2008, 2009b) showed various crystals in some species of the tribe Astereae. Meric (2009a) also observed $\mathrm{CaOx}$ crystals in the tribe Inuleae. Although, the size and location of the crystals in plants might be affected by physical, chemical, and biological conditions such as temperature, light, pressure, $\mathrm{pH}$, ion concentration, and herbivory (Franceschi and Horner, 1980; Molano-Flores, 2001; Kuo-Huang et al., 2007), it is considered that crystal formation within the cell is under genetic control and species specific (Kausch and Horner, 1982; Ilarslan et al., 2001; Horner et al., 2009). Thus the type, and presence or absence of crystals may be represented as a taxonomic character (Prychid and Rudall, 1999; Lersten and Horner, 2000; Horner et al., 2012). The present study is a part of an ongoing project to study $\mathrm{CaOx}$ crystals in Asteraceae. This study aims to provide additional data on the presence, types and specific locations of $\mathrm{CaOx}$ crystals to contribute to the solution of taxonomic problems of tribe Cardueae.

\section{Materials and methods}

Plants were collected from natural habitats in Edirne (Turkey). Each taxon was identified using the classification criteria in the Flora of Turkey and the East Aegean Islands (Vol. 5) (Davis, 1975). Voucher specimens were deposited in EDTU (Herbarium of Faculty of Sciences, Trakya University, Edirne, Turkey). The taxa examined were: Arctium minus Bernh., Carduus candicans Waldst. \& Kit., C. nutans L., C. pycnocephalus L., Cirsium arvense (L.) Scop., C. creticum d'Urv., C. vulgare (Savi) Ten., Jurinea consanguinea DC., Silybum marianum (L.) Gaertn., Tyrimnus leucographus Cass., and Xeranthemum annuum L. belonging to the subtribe Carduinae and Carthamus dentatus Vahl., C. lanatus L., Centaurea cyanus L., C. diffusa Lam., C. iberica Trevir ex Spreng., C. salonitana Vis., and C. solstitialis L. belonging to the subtribe Centaureinae.

For light microscopy, materials were fixed in ethanol and glacial acetic acid $(3: 1 \mathrm{v} / \mathrm{v})$ at room temperature overnight and changed to $70 \%$ ethanol. Hand-sections were made from fixed stems and leaves. Corollas, stamens, ovaries, and styles were dissected out of florets under a stereomicroscope. The samples were treated with $2.5 \%$ Clorox (sodium hypochlorite) for $4 \mathrm{~h}$. After a graded ethanol series, the samples were infiltrated with Xylene series (Merck, 108661), mounted in Entellan (Merck, 107961) on slides, and covered with cover slips (Ilarslan et al., 2001). In cleared tissues, crystals were examined with bright-field light microcopy. Selected images were captured with an Olympus (C-5060 Wide Zoom) digital camera and processed in PhotoShop 7.0 (Adobe, San Jose, California).

Measurements of the crystals were carried out using Image-Pro Plus, version 5.1 (Media Cybernetics, Silver Spring, MD). For analysis, the diameters of the druses, and the lengths of the styloids and prismatic crystals were measured. One hundred crystals for each tissue and each crystal type were measured from ten randomly chosen regions. The averages and standard deviations of data were calculated. The numerical data were established according to 14 characters including the absence / presence, type, and measurement of the crystals in the species (Table 1). Similarities between the species were calculated by Bray-Curtis index 
Table 1. Crystal characters used for the numerical analysis.

\begin{tabular}{|c|c|c|}
\hline $\begin{array}{c}\text { Number } \\
\text { of characters }\end{array}$ & Characters & Scoring \\
\hline \multicolumn{3}{|l|}{ Stem } \\
\hline \multirow[t]{2}{*}{1.} & Crystal absent in epidermis & 0 \\
\hline & Styloid present in epidermis & 1 \\
\hline \multirow[t]{2}{*}{2.} & Crystal absent in trichomes & 0 \\
\hline & Styloid present in trichomes & 1 \\
\hline \multirow[t]{3}{*}{3.} & Crystal absent in cortex & 0 \\
\hline & Raphide present in cortex & 1 \\
\hline & Prismatic present in cortex & 2 \\
\hline \multirow[t]{4}{*}{4.} & Crystal absent in pith & 0 \\
\hline & Raphide present in pith & 1 \\
\hline & Prismatic present in pith & 2 \\
\hline & Druse present in pith & 3 \\
\hline \multicolumn{3}{|l|}{ Leaf } \\
\hline \multirow[t]{2}{*}{5} & Crystal absent in epidermis & 0 \\
\hline & Styloid present in epidermis & 1 \\
\hline \multirow[t]{2}{*}{6} & Crystal absent in trichomes & 0 \\
\hline & Styloid present in trichomes & 1 \\
\hline \multirow[t]{2}{*}{7} & Crystal absent in mesophyll & 0 \\
\hline & Styloid present in mesophyll & 1 \\
\hline \multirow[t]{2}{*}{8} & Crystal absent in bundle sheath & 0 \\
\hline & Styloid present in bundle sheath & 1 \\
\hline \multicolumn{3}{|l|}{ Flower } \\
\hline \multirow[t]{2}{*}{9} & Crystal absent in corolla & 0 \\
\hline & Styloid present in corolla & 1 \\
\hline \multirow[t]{2}{*}{10} & Crystal absent in anther & 0 \\
\hline & Styloid present in anther & 1 \\
\hline \multirow[t]{2}{*}{11} & Crystal absent in filament & 0 \\
\hline & Styloid present in filament & 1 \\
\hline \multirow[t]{2}{*}{12} & Crystal absent in style & 0 \\
\hline & Styloid present in style & 1 \\
\hline \multirow[t]{2}{*}{13} & Styloid present in ovary & 0 \\
\hline & Prismatic present in ovary & 1 \\
\hline \multirow[t]{3}{*}{14} & Crystal length in ovary $(\mu \mathrm{m})<25$ & 0 \\
\hline & Crystal length in ovary $(\mu \mathrm{m}) 25-45$ & 1 \\
\hline & Crystal length in ovary $(\mu \mathrm{m})>45$ & 2 \\
\hline
\end{tabular}

of similarity and the similarity values were analyzed using Bray-Curtis Cluster (single linkage) analysis. A dendrogram was obtained by BioDiversity Pro version 2.0 (McAleece $e t$ al., 1997).

The histochemical determination of $\mathrm{CaOx}$ crystals was performed by the Yasue (1969) procedure on the cleared tissues. Cleared samples were immersed in $5 \%$ aqueous $\mathrm{AgNO}_{3}$ (Merck) for $15 \mathrm{~min}$, and thoroughly rinsed in distilled water. The samples were stained with saturated rubeanic acid (Dithiooxamide, Sigma) in $70 \%$ ethanol for 1 min. Control samples were treated with $5 \%$ acetic acid, $10 \%$ hydrochloric acid, $3 \%$ nitric acid or $4 \%$ sulfuric acid (Molano-Flores, 2001).

\section{Results}

The $\mathrm{CaOx}$ crystals were examined in 18 species of the tribe Cardueae using bright field microscopy. They were easily observed since the clearing technique removed all the cytoplasm except for the cell walls and crystals. The CaOx crystals displayed a different pattern in the tissues and organs of the species investigated. Their morphologies, crystal measurements, and distributions in tissues of all 18 species are shown in Table 2.

\section{Subtribe Carduinae}

Arctium minus. No crystals were present in the primary structure of stem of A. minus, while prismatic crystals were observed in the pith parenchyma cells of the secondary stem (Figure 1A). The frequency of these crystals in the tissue was about $10 \%$. No crystal was found in the leaves. Styloids were present in the corolla cells (Figure 1B). Styloids were also observed in the endothecial layer of the anther and in the style cells. In the ovary cells, prismatics were observed (Figure 1C). These crystals were short and multifaceted. No crystals were found in the filament.

Carduus candicans. Styloids were observed in the corolla cells, while no crystals were found in the stem and leaf tissues. Styloids were also present in the connective tissue of the anther and in the filament. Prismatics were present in the ovary cells (Figure 1D), while no crystals were found in the style cells.

Carduus nutans. Prismatics were observed in the stem pith parenchyma (Figure 1E), while no crystals were found in the leaf or in the cortex and epidermal cells of the stem. Styloids were present in the corolla cells and in the connective tissue of the anther. Styloids were also observed in the filament. While no crystals were present in the style cells, large prismatics were observed in the ovary cells (Figure 1F).

Carduus pycnocephalus. Druses were observed in the stem pith parenchyma cells (Figure 1G), while no crystals were found in the stem cortex and epidermal cells or leaf tissues. Styloids were present in the corolla cells and in the endothecial layer of the anther. They were also in the filament. While no crystals were present in the style cells, large prismatics were observed in the ovary (Figure 1H).

Cirsium arvense. Small styloids were observed in the stem epidermal cells. They were also observed in the stem trichomes. No crystals were found in the cortex or the pith parenchyma cells of the stem. Styloids were present in the epidermal cells of the leaf (Figure 2A), and were present in the multicellular-unbranched trichomes of the leaf. No crystals were observed in the mesophyll layer. Styloid crystals were also present in the corolla cells and in the connective tissue of the anther. No crystals were found in the endothecial layer of the anther. Small styloids were observed in the filament and in the style cells. Prismatic crystals were present in the ovary cells. 


\section{Ciler Kartal}

Table 2. Calcium oxalate crystal morphologies and locations within the tissues of Cardueae.

\begin{tabular}{|c|c|c|c|c|c|c|c|}
\hline & Stem & Leaf & Corolla & $\begin{array}{l}\text { Anther } \\
\text { shape and } \\
\text { size }(\mu \mathrm{m})\end{array}$ & Filament & Style & Ovary \\
\hline $\begin{array}{l}\text { Carduinae } \\
\text { Arctium minus }\end{array}$ & $\begin{array}{c}\text { prismatics (pith) } \\
9.35 \pm 2.68\end{array}$ & --- & $\begin{array}{c}\text { styloids } \\
11.98 \pm 2.27\end{array}$ & $\begin{array}{c}\text { styloids } \\
8.06 \pm 1.54\end{array}$ & --- & $\begin{array}{c}\text { styloids } \\
9.52 \pm 2.38\end{array}$ & $\begin{array}{l}\text { prismatics } \\
9.38 \pm 1.29\end{array}$ \\
\hline Carduus candicans & --- & --- & $\begin{array}{c}\text { styloids } \\
10.91 \pm 4.09\end{array}$ & $\begin{array}{c}\text { styloids } \\
17.81 \pm 4.35\end{array}$ & $\begin{array}{c}\text { styloids } \\
5.25 \pm 1.27\end{array}$ & --- & $\begin{array}{c}\text { prismatics } \\
35.52 \pm 7.73\end{array}$ \\
\hline Carduus nutans & $\begin{array}{c}\text { prismatics (pith) } \\
11.78 \pm 5.24\end{array}$ & --- & $\begin{array}{l}\text { styloids } \\
7.55 \pm 1.49\end{array}$ & $\begin{array}{c}\text { styloids } \\
12.28 \pm 2.55\end{array}$ & $\begin{array}{c}\text { styloids } \\
5.63 \pm 1.14\end{array}$ & --- & $\begin{array}{c}\text { prismatics } \\
52.28 \pm 15.97\end{array}$ \\
\hline Carduus pycnocephalus & $\begin{array}{l}\text { druses (pith) } \\
8.95 \pm 1.10\end{array}$ & --- & $\begin{array}{c}\text { styloids } \\
7.99 \pm 1.93\end{array}$ & $\begin{array}{c}\text { styloids } \\
8.40 \pm 1.43\end{array}$ & $\begin{array}{c}\text { styloids } \\
3.98 \pm 0.69\end{array}$ & --- & $\begin{array}{c}\text { prismatics } \\
52.21 \pm 16.56\end{array}$ \\
\hline Cirsium arvense & $\begin{array}{c}\text { styloids } \\
\text { (epidermis) } \\
4.59 \pm 0.98 \\
\text { (trichome) } \\
8.90 \pm 2.68\end{array}$ & $\begin{array}{c}\text { styloids } \\
\text { (epidermis) } \\
6.13 \pm 1.53 \\
\text { (trichome) } \\
7.01 \pm 3.14\end{array}$ & $\begin{array}{c}\text { styloids } \\
7.01 \pm 1.27\end{array}$ & $\begin{array}{c}\text { styloids } \\
11.11 \pm 2.14\end{array}$ & $\begin{array}{c}\text { styloids } \\
4.57 \pm 1.00\end{array}$ & $\begin{array}{c}\text { styloids } \\
4.98 \pm 0.76\end{array}$ & $\begin{array}{c}\text { prismatics } \\
19.34 \pm 4.84\end{array}$ \\
\hline Cirsium creticum & --- & --- & $\begin{array}{c}\text { styloids } \\
15.37 \pm 4.97\end{array}$ & --- & --- & $\begin{array}{c}\text { styloids } \\
4.34 \pm 1.07\end{array}$ & $\begin{array}{c}\text { prismatics } \\
53.72 \pm 9.80\end{array}$ \\
\hline Cirsium vulgare & $\begin{array}{c}\text { styloids } \\
\text { (epidermis) } \\
2.53 \pm 0.71 \\
\text { (trichome) } \\
15.51 \pm 4.22 \\
\text { prismatics (pith) } \\
16.76 \pm 2.63\end{array}$ & --- & $\begin{array}{c}\text { styloids } \\
22.25 \pm 5.05\end{array}$ & $\begin{array}{c}\text { styloids } \\
19.32 \pm 4.11\end{array}$ & --- & $\begin{array}{c}\text { styloids } \\
4.42 \pm 0.73\end{array}$ & $\begin{array}{c}\text { prismatics } \\
64.35 \pm 12.72\end{array}$ \\
\hline Jurinea consanguinea & --- & --- & --- & --- & --- & --- & $\begin{array}{c}\text { prismatics } \\
25.98 \pm 7.04\end{array}$ \\
\hline Silybum marianum & $\begin{array}{c}\text { raphides } \\
\text { (cortex) } \\
13.20 \pm 3.44 \\
\text { (pith) } \\
36.19 \pm 5.43\end{array}$ & --- & $\begin{array}{c}\text { styloids } \\
8.86 \pm 2.15\end{array}$ & --- & --- & $\begin{array}{c}\text { styloids } \\
14.09 \pm 3.74\end{array}$ & $\begin{array}{c}\text { prismatics } \\
49.60 \pm 12.37\end{array}$ \\
\hline Tyrimnus leucographus & --- & --- & --- & $\begin{array}{c}\text { styloids } \\
4.98 \pm 0.99\end{array}$ & --- & --- & $\begin{array}{c}\text { prismatics } \\
5.33 \pm 1.27\end{array}$ \\
\hline Xeranthemum annuum & --- & --- & --- & --- & --- & $\begin{array}{c}\text { styloids } \\
7.03 \pm 1.42\end{array}$ & $\begin{array}{c}\text { styloids } \\
8.93 \pm 1.94\end{array}$ \\
\hline $\begin{array}{l}\text { Centaureinae } \\
\text { Carthamus dentatus }\end{array}$ & $\begin{array}{c}\text { prismatics } \\
\text { (cortex) } \\
5.24 \pm 1.62 \\
\text { (pith) } \\
8.74 \pm 1.95\end{array}$ & $\begin{array}{c}\text { styloids } \\
\text { (mesophyll) } \\
5.35 \pm 1.20 \\
\text { (bundle sheath) } \\
10.55 \pm 1.89\end{array}$ & $\begin{array}{c}\text { styloids } \\
10.83 \pm 2.34\end{array}$ & $\begin{array}{c}\text { styloids } \\
6.44 \pm 1.08\end{array}$ & $\begin{array}{c}\text { styloids } \\
2.60 \pm 0.50\end{array}$ & $\begin{array}{c}\text { styloids } \\
5.49 \pm 0.89\end{array}$ & $\begin{array}{c}\text { prismatics } \\
10.02 \pm 2.39\end{array}$ \\
\hline Carthamus lanatus & $\begin{array}{c}\text { prismatics } \\
\text { (cortex) } \\
4.56 \pm 1.50 \\
\text { (pith) } \\
5.84 \pm 1.56\end{array}$ & $\begin{array}{c}\text { styloids } \\
\text { (mesophyll) } \\
4.55 \pm 1.15 \mathrm{fm} \\
\text { (bundle sheath) } \\
10.60 \pm 2.39\end{array}$ & $\begin{array}{c}\text { styloids } \\
12.24 \pm 2.86\end{array}$ & $\begin{array}{c}\text { styloids } \\
6.52 \pm 1.41\end{array}$ & $\begin{array}{c}\text { styloids } \\
4.01 \pm 0.90\end{array}$ & $\begin{array}{c}\text { styloids } \\
7.99 \pm 1.28\end{array}$ & $\begin{array}{c}\text { prismatics } \\
10.22 \pm 1.13\end{array}$ \\
\hline Centaurea cyanus & --- & --- & $\begin{array}{c}\text { styloids } \\
11.90 \pm 2.06\end{array}$ & --- & --- & --- & $\begin{array}{c}\text { prismatics } \\
15.14 \pm 2.39\end{array}$ \\
\hline Centaurea diffusa & --- & --- & $\begin{array}{c}\text { styloids } \\
13.68 \pm 4.98\end{array}$ & $\begin{array}{c}\text { styloids } \\
5.81 \pm 1.17\end{array}$ & --- & --- & $\begin{array}{c}\text { prismatics } \\
27.04 \pm 4.24\end{array}$ \\
\hline Centaurea iberica & --- & --- & $\begin{array}{c}\text { styloids } \\
12.58 \pm 2.70\end{array}$ & --- & --- & --- & $\begin{array}{c}\text { prismatics } \\
14.57 \pm 2.33\end{array}$ \\
\hline Centaurea salonitana & --- & --- & $\begin{array}{c}\text { styloids } \\
26.07 \pm 6.66\end{array}$ & --- & --- & --- & $\begin{array}{c}\text { prismatics } \\
10.95 \pm 1.09\end{array}$ \\
\hline Centaurea solstitialis & --- & --- & $\begin{array}{c}\text { styloids } \\
21.29 \pm 1.17\end{array}$ & $\begin{array}{c}\text { styloids } \\
7.09 \pm 1.18\end{array}$ & --- & --- & $\begin{array}{c}\text { prismatics } \\
9.87 \pm 1.64\end{array}$ \\
\hline
\end{tabular}





Figure 1. CaOx crystals in Arctium minus and Carduus species. A) Prisms in secondary stem pith cells of A. minus. B) Styloids in corolla cells of A. minus. C) Prisms in ovary cells of A. minus. D) Prisms in the ovary cells of C. candicans. E) Prisms in stem pith parenchyma of $C$. nutans. F) Prisms in ovary cells of $C$. nutans. G) Druse in stem pith parenchyma cells of $C$. pycnocephalus. H) Prisms in ovary cells of $C$. pycnocephalus. Scale bars $=10 \mu \mathrm{m}$. 

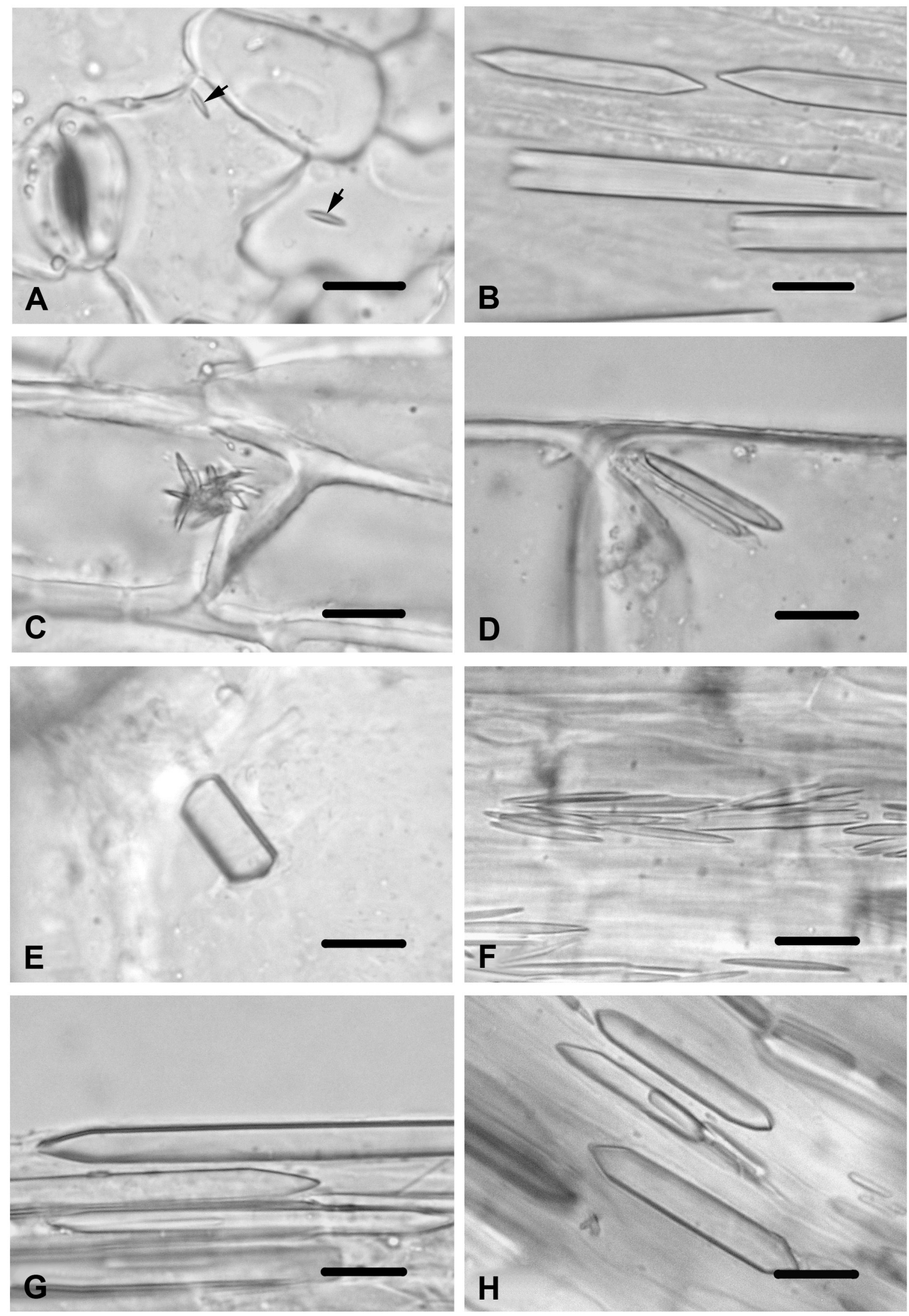

Figure 2. Calcium oxalate crystals in Cirsium species and Jurinea consanguinea. A) Styloids in epidermal cell of leaf of C. arvense (arrows). B) Prisms in ovary cells of C. creticum. C) Styloids in stem epidermal cells of C. vulgare. D) Styloids in stem trichomes of $C$. vulgare. E) Prism in stem pith parenchyma cells of $C$. vulgare, F) Styloids in connective tissue of anther in C. vulgare. G) Prisms in ovary cells of $C$. vulgare. $\mathbf{H}$ ) Prisms in ovary cells of $J$. consanguinea. Scale bars $=10 \mu \mathrm{m}$. 
Cirsium creticum. Styloids were observed in the corolla cells. They were also observed in the style cells. Large prismatics were viewed in the ovary cells (Figure 2B). No crystals were found in tissues of the stem, leaf or stamen.

Cirsium vulgare. The small styloids were observed in the stem epidermal cells of $C$. vulgare (Figure 2C). Styloids were also found in the trichomes of the stem (Figure 2D). Prismatics were viewed in the stem pith parenchyma cells (Figure 2E). No crystals were found in the stem cortex parenchyma cells and in the leaf tissues. Styloids were present in the corolla cells. They were also present in the connective tissue of the anther (Figure 2F). No crystals were seen in the endothecial layer of the anther or in the filament. Small styloids were observed in the style cells, while large prismatics were found in the ovary cells (Figure $2 \mathrm{G})$.

Jurinea consanguinea. Prismatics were observed in the ovary cells (Figure $2 \mathrm{H}$ ), while no crystals were found in the other tissues.

Silybum marianum. Acicular raphides were observed in the stem pith parenchyma (Figure 3A) and in the cortex parenchyma cells (Figure 3B). Styloids were found in the corolla cells (Figure 3C), and were found in the style cells. In the ovary cells, large prisms were present (Figure 3D). No crystal was observed in the anther and filament.

Tyrimnus leucographus. Styloids were observed only in the anther. The ovary had small typical prismatics (Figure $3 \mathrm{E})$. No crystals were found in the stem, leaf, corolla, filament or style.

Xeranthemum annuum. Styloids were present in the style cells and in the ovary cells (Figure 3F). No crystals were found in the other tissues and organs.

\section{Subtribe Centaureinae}

Carthamus dentatus. Prismatics with various shapes were observed in the cortex parenchyma cells and pith parenchyma cells of the stem, while no crystals were found in the stem and leaf epidermal cells. In the leaf mesophyll tissues and bundle sheath cells, styloids were present. Styloids were observed in the corolla cells and in the endothecial cells of the anther. Styloids were also found in the filament cells and in the style cells. Prismatics were observed in the ovary cells.

Carthamus lanatus. This species displayed identical properties with $C$. dentatus in respect to $\mathrm{CaOx}$ crystals. Prismatics of various shapes were observed in the cortex parenchyma cells and in the pith parenchyma cells of the stem (Figure $4 \mathrm{~A}$ ), while no crystals were found in the stem and in the leaf epidermal cells. In the leaf mesophyll tissues (Figure 4B) and bundle sheath cells (Figure 4C), styloids were present. Styloids were found in the corolla cell and in the endothecial cells of the anther. Styloids were also seen in the filament cells and in the style cells. Prismatics were observed in the ovary cells (Figure 4D).

Centaurea cyanus. Styloids were observed in the corolla cells. Prismatics were present in the ovary cells (Figure $5 \mathrm{~A}$ ), while no crystals were found in the other tissues and organs.

Centaurea diffusa. Styloids were observed in the corolla cells (Figure 5B) and in the endothecial layer of the anther. Prismatics were present in the ovary cells (Figure 5C),

Table 3. Bray-Curtis similarity (\%) for crystal characters of Cardueae

\begin{tabular}{|c|c|c|c|c|c|c|c|c|c|c|c|c|c|c|c|c|c|c|}
\hline \multicolumn{19}{|c|}{ Similarity Matrix } \\
\hline & Arc min & Car can & Car nut & Car pyc & Cart den & Cart lan & Cen cya & Cen dif & Cen ibe & Cen sal & Cen sol & Cir arv & Cir cre & Cir vul & Jur con & Sil mar & Tyr leu & Xer ann \\
\hline Arc min & $*$ & 54,5455 & 71,4286 & 66,6667 & 70,5882 & 70,5882 & 50 & 60 & 50 & 50 & 66,6667 & 53,3333 & 54,5455 & 75 & 25 & 61,5385 & 28,5714 & 28,5714 \\
\hline Car can & * & * & 76,9231 & 71,4286 & 50 & 50 & 57,1429 & 88,8889 & 57,1429 & 57,1429 & 75 & 57,1429 & 60 & 53,3333 & 57,1429 & 50 & 33,3333 & 0 \\
\hline Car nut & $*$ & $*$ & $*$ & 94,1176 & 63,1579 & 63,1579 & 40 & 66,6667 & 40 & 40 & 54,5455 & 47,0588 & 61,5385 & 77,7778 & 340 & 66,6667 & 22,2222 & 0 \\
\hline Car pyc & $*$ & $*$ & * & * & 60 & 60 & 36,3636 & 61,5385 & 36,3636 & 36,3636 & 50 & 44,4444 & 57,1429 & 73,6842 & 36,3636 & 62,5 & 20 & 0 \\
\hline Cart den & $*$ & * & * & * & * & 100 & 30,7692 & 40 & 30,7692 & 30,7692 & 42,8571 & 50 & 37,5 & 57,1429 & 15,3846 & 55,5556 & 16,6667 & 16,6667 \\
\hline Cart lan & $*$ & $*$ & $*$ & $*$ & $*$ & $*$ & 30,7692 & 40 & 30,7692 & 30,7692 & 42,8571 & 50 & 37,5 & 57,1429 & 915,3846 & 55,5556 & 16,6667 & 16,6667 \\
\hline Cen cya & $*$ & $*$ & $*$ & $*$ & $*$ & $*$ & $*$ & 66,6667 & 100 & 100 & 80 & 36,3636 & 57,1429 & 33,3333 & 30 & 44,4444 & 66,6667 & 0 \\
\hline Cen dif & $*$ & $*$ & $*$ & $*$ & $*$ & $*$ & * & $*$ & 66,6667 & 766,6667 & 85,7143 & 46,1538 & 66,6667 & 57,1429 & 96,6667 & 54,5455 & 40 & 0 \\
\hline Cen ibe & $*$ & $*$ & $*$ & $*$ & $*$ & $*$ & $*$ & $*$ & $*$ & 100 & 80 & 36,3636 & 57,1429 & 33,3333 & 30 & 44,4444 & 66,6667 & 0 \\
\hline Cen sal & $*$ & * & * & * & * & $*$ & $*$ & $*$ & $*$ & * & 80 & 36,3636 & 57,1429 & 33,3333 & 30 & 44,4444 & 66,6667 & 0 \\
\hline Cen sol & $*$ & * & * & $*$ & * & $*$ & $*$ & $*$ & $*$ & * & $*$ & 50 & 50 & 46,1538 & 340 & 40 & 50 & 0 \\
\hline Cir arv & $*$ & * & * & * & * & $*$ & $*$ & * & $*$ & * & * & * & 42,8571 & 63,1579 & 18,1818 & 37,5 & 20 & 20 \\
\hline Cir cre & $*$ & * & $*$ & * & * & $*$ & * & $*$ & $*$ & * & $*$ & $*$ & $*$ & 66,6667 & 757,1429 & 83,3333 & 33,3333 & 33,3333 \\
\hline Cir vul & $*$ & * & * & $*$ & * & $*$ & $*$ & $*$ & $*$ & * & * & $*$ & $*$ & * & 33,3333 & 70,5882 & 18,1818 & 18,1818 \\
\hline Jur con & $*$ & $*$ & $*$ & $*$ & $*$ & $*$ & $*$ & $*$ & $*$ & $*$ & $*$ & $*$ & * & * & $*$ & 44,4444 & 66,6667 & 0 \\
\hline Sil mar & $*$ & * & * & * & $*$ & $*$ & * & $*$ & $*$ & $*$ & $*$ & * & * & * & $*$ & $*$ & 25 & 25 \\
\hline Tyr leu & $*$ & $*$ & $*$ & $*$ & $*$ & $*$ & $*$ & $*$ & $*$ & $*$ & $*$ & $*$ & $*$ & $*$ & $*$ & $*$ & $*$ & 0 \\
\hline Xer ann & $*$ & $*$ & $*$ & $*$ & * & $*$ & $*$ & $*$ & $*$ & $*$ & * & $*$ & $*$ & $*$ & $*$ & * & $*$ & $*$ \\
\hline
\end{tabular}



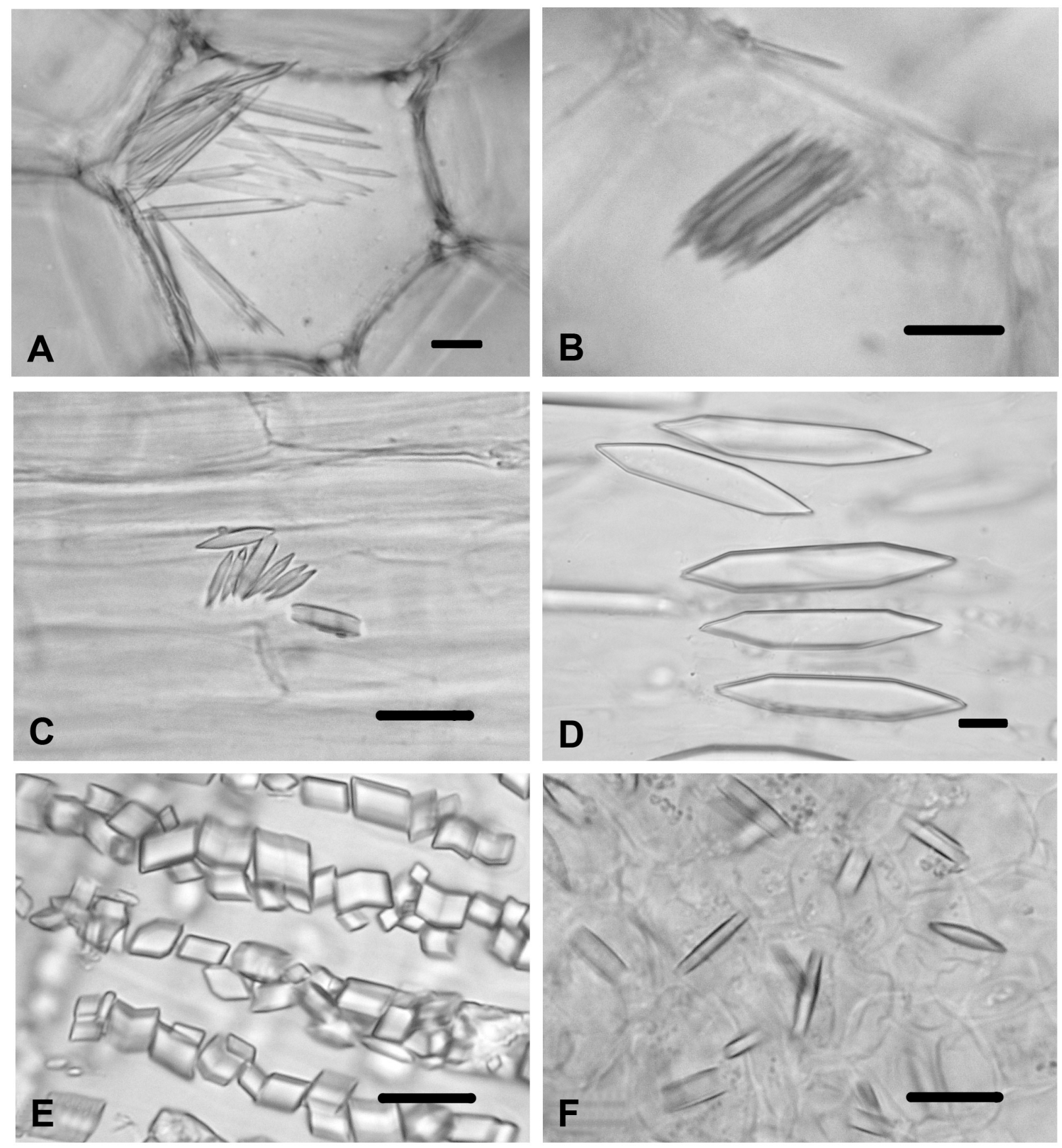

Figure 3. CaOx in Silybum marianum, Tyrimnus leucographus and Xeranthemum annuum. A) Raphides in stem pith cells of S. marianum. B) Raphides in stem cortex of $S$. marianum. C) Styloids in corolla cells of $S$. marianum. D) Large prisms in ovary cells of $S$. marianum.

E) Prisms in ovary cells of T. leucographus. F) Styloids in ovary cells $X$. annuum. Scale bars $=10 \mu \mathrm{m}$.

while no crystals were found in the stem, leaf, filament or style cells.

Centaurea iberica. Styloids were observed in the corolla cells while prismatics were present in the ovary cells (Figure 5D). No crystals were found in the other tissues and organs.

Centaurea salonitana. Large styloids were observed in the corolla cells while prismatics were present in the ovary cells
(Figure 5E). No crystals were found in the other tissues and organs.

Centaurea solstitialis. Styloids were observed in the corolla cells $\int \mathrm{m}$ and in the endothecial layer of the anther. Small prismatics were present in the ovary cells (Figure 5F), while no crystals were found in the other tissues and organs.

It was observed that styloids and prismatics were the most commonly found crystals in the tissues and organs of 

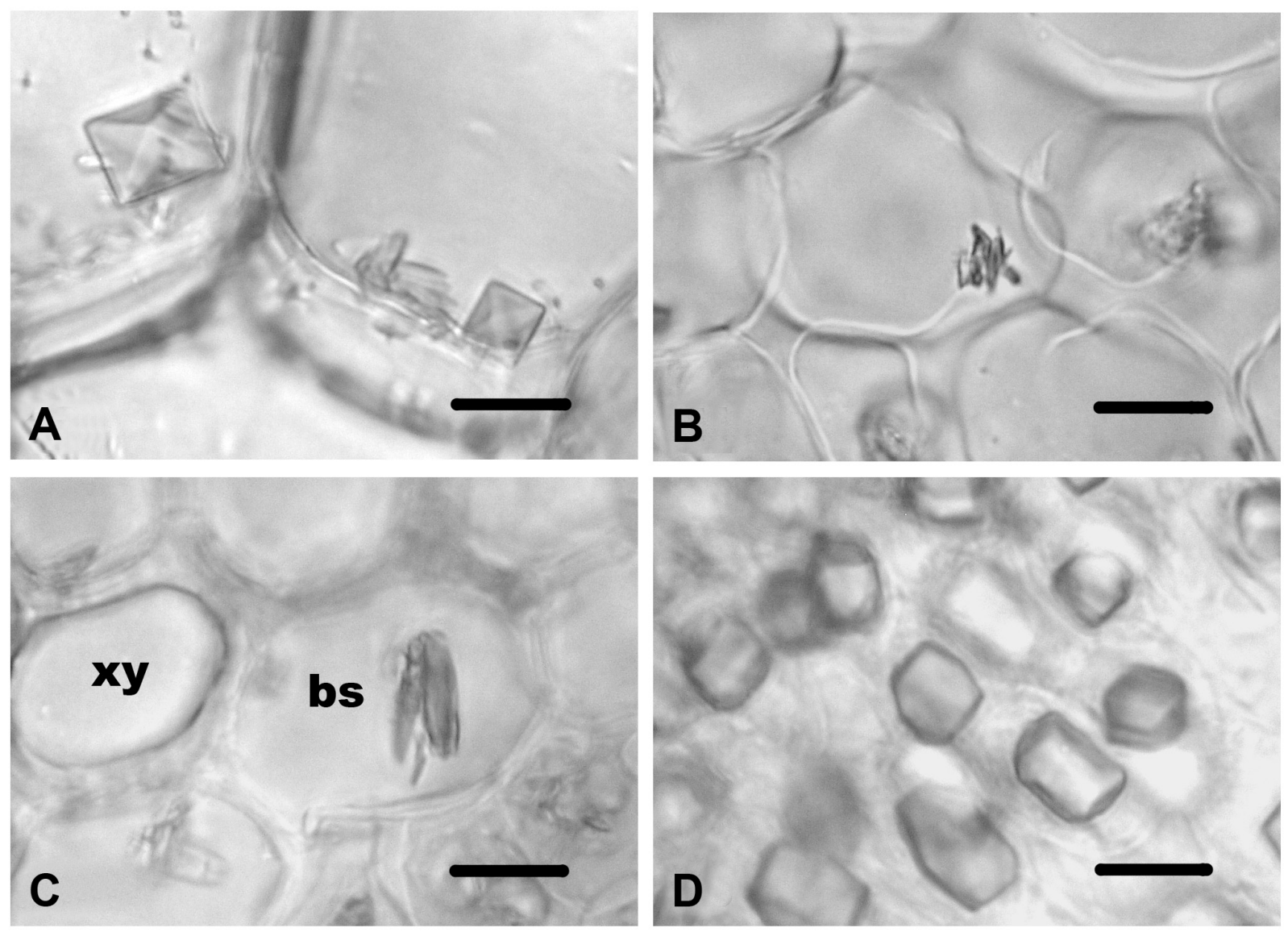

Figure 4. CaOx crystals in Carthamus lanatus. A) Prisms in pith parenchyma cells in of stem in C. lanatus. B) Styloids in leaf mesophyll tissues of $C$. lanatus. C) Styloids in bundle sheath cells of $C$. lanatus. D) Prisms in ovary cells $C$. lanatus. xy-xylem; bs-bundle sheath cell. Scale bars $=10 \mu \mathrm{m}$.

the 18 species examined. Styloids were observed (if present) in the leaf, corolla, anther, filament, style, and ovary (only Xerantheтит аппиит) tissues. Prismatics were common in almost all the ovaries of the species investigated, except for $X$. anпиum. Raphides were only observed in the stem cortex and pith parenchyma cells of Silybum marianum, while druses were only seen in the stem pith cells of Carduus pycnocephalus.

The crystal measurements of the 15 species that had styloids in the corollas ranged from $7.01 \mu \mathrm{m}$ (Cirsium arvense) to $26.07 \mu \mathrm{m}$ (Centaurea salonitana). These measurements were categorized in three sections; $(1)<10 \mu \mathrm{m}$ in four species, (2) $10-20 \mu \mathrm{m}$ in eight species, and (3) $>20 \mu \mathrm{m}$ in three species. All the species of the subtribe Centaureinae had styloids in their corollas and these crystals were longer than 10 $\mu \mathrm{m}$. The species of the subtribe Carduinae displayed differences with regard to the styloids in their corollas (absence/ presence and measurement) (Table 2).

Similarly, the measurements of the crystals in ovaries were also categorized in three sections; $(1)<25 \mu \mathrm{m}$ in ten species, (2) $25-45 \mu \mathrm{m}$ in three species, and (3) $>45 \mu \mathrm{m}$ in five species. Almost all of the species of the subtribe Cen- taureinae had prismatics shorter than $25 \mu \mathrm{m}$ in their ovaries except for Centaurea diffusa (length: $27.04 \mu \mathrm{m}$ ).

Figure 6 shows a phenogram obtained based on the $\mathrm{CaOx}$ crystal characteristics of the 18 species of the tribe Cardueae investigated. The phenogram showed that Xeranthemum annиит was distinctly separated from the rest of the species of the subtribes Carduinae and Centaureinae. Only two groups had $100 \%$ similarity values: two species Carthamus and three species of Centaurea both of the Centaureinae. Carthamus is the genus that recovered its species as a group, while none of the three species of Cirsium grouped together. The similarity values obtained based on the $\mathrm{CaOx}$ crystal characteristics of the species are given in the Table 3.

\section{Discussion}

The $\mathrm{CaOx}$ crystals are widely distributed in the Plant Kingdom and are found in over 215 families (Franceschi and Horner, 1980). They are formed from endogenously synthesized oxalic acid and Ca taken from the environment, and are produced and accumulated in to species-specific morphologies (Franceschi and Nakata, 2005). Previous studies 

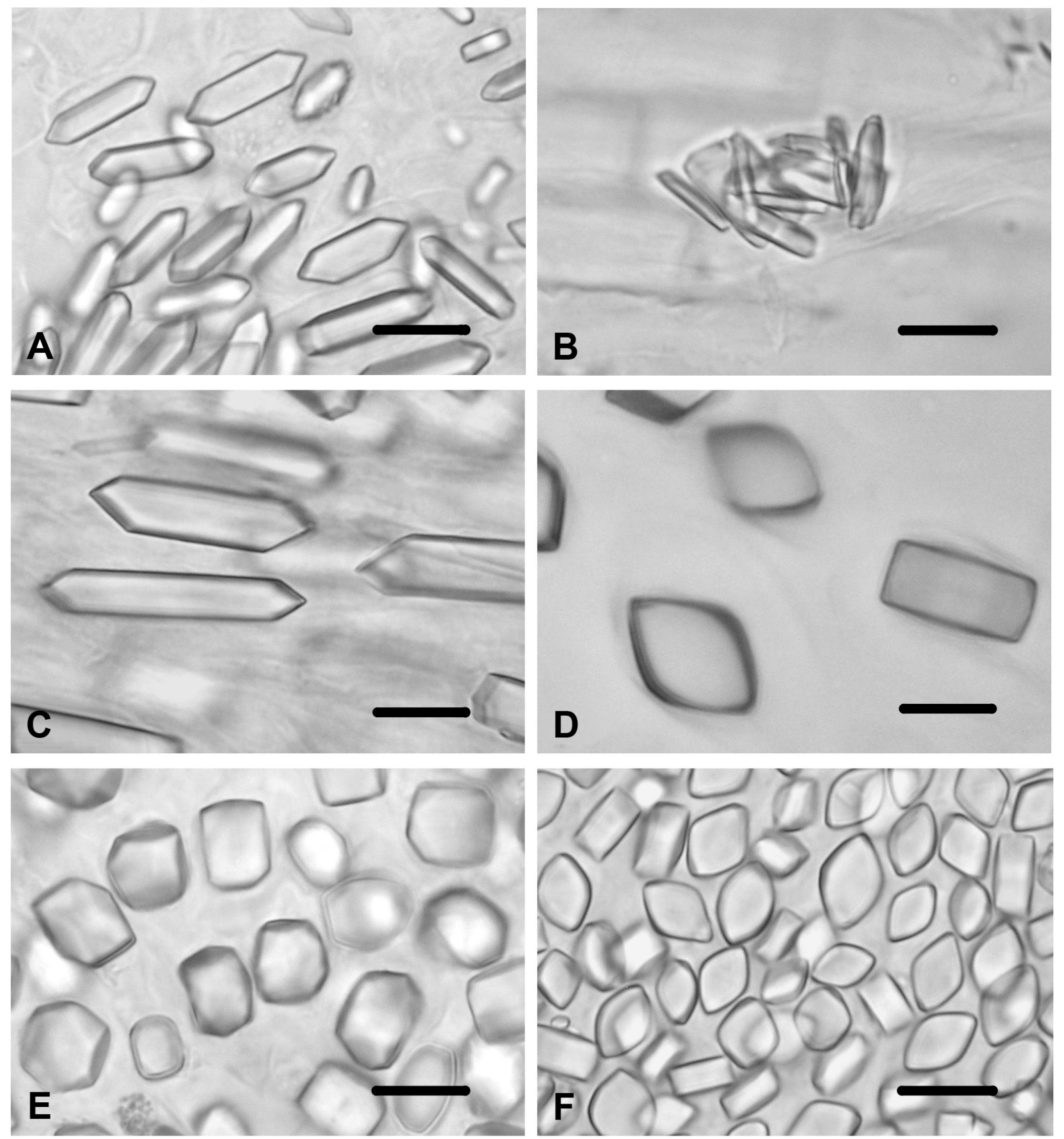

Figure 5. CaOx crystals in Centaurea species. A) Prisms in ovary cells of $C$. cyanus. B) Styloids in corolla cells of $C$. diffusa. C) Prisms in ovary cells of $C$. diffusa. D) Prisms in ovary cells of $C$. iberica. E) Prisms in ovary cells of $C$. salonitana. F) Prisms in ovary cells of C. solstitialis. Scale bars $=10 \mu \mathrm{m}$.

have described CaOx crystals in Asteraceae (Dormer, 1961, 1962; Horner, 1977; Meric and Dane, 2004; Meric, 2008, 2009a, b). In the present study, the morphologies and locations of $\mathrm{CaOx}$ crystals have been examined in the Cardueae tribe. Crystals in this tribe generally display two types of morphologies, namely styloids and prismatics. Druses are only observed in stem pith parenchyma cells of Carduus pycnocephalus, while raphides are found in both the stem pith parenchyma and cortex parenchyma cells of Silybum marianum. Styloids are fixed in the leaf, corolla, anther, filament, and style tissues (if present). The prismatics, in their various forms, are found in the ovaries of almost all of the examined species, except for Xeranthemum annuиm, which has styloids in the ovary cells.

Various crystal types, such as raphides (Silybum marianum), druses (Carduus pycnocephalus), styloids (Cirsium vulgare and $C$. arvense), and prismatics (Arctium minus, Carduus nutans, Carthamus lanatus, and $C$. dentatus), have 


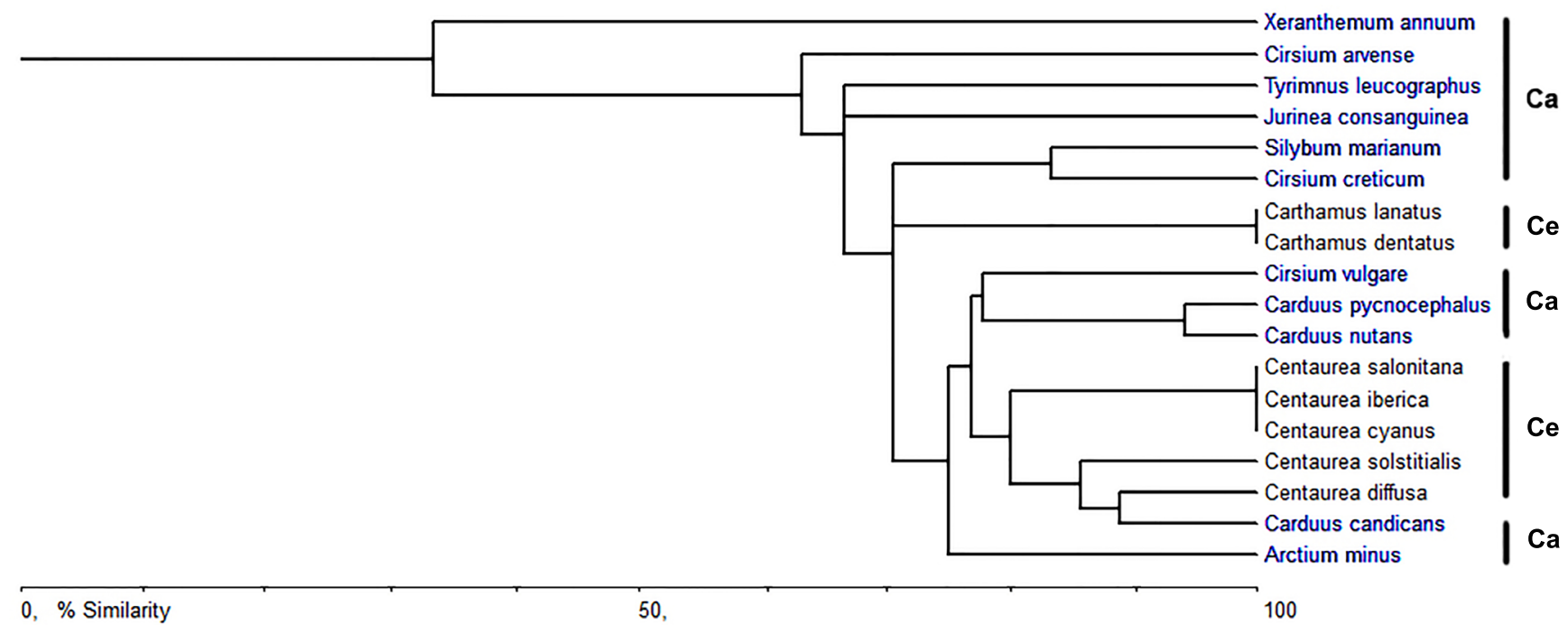

Figure 6. Phenogram based on the $\mathrm{CaOx}$ crystal characteristics of the tribe Cardueae. Ca-Carduinae; $\mathrm{Ce}-\mathrm{Centaureinae}$

been found in stem tissues. Previous studies have reported that Inula graveolens (Inuleae tribe) has druses in the stem, while Aster squamatus (Astereae tribe) contains both styloids and prismatics (Meric, 2009a, b).

Surprisingly, the presence of crystals in the leaf tissues of the investigated species is rare compared to their presence in the stem. Conversely, Franceschi and Horner (1980) reported that crystals are less common in the stem than in leaf tissues, and that they are found only as styloids in the leaf mesophyll tissue and bundle sheath of Carthamus species and in the leaf epidermis of Cirsium arvense. It has been suggested that these crystals provide structural support in the leaf tissues. Further, the presence of crystals in trichomes is less common in the Cardueae tribe as they are observed only as styloids in the stem and leaf trichomes of $C$. arvense and in the stem trichomes of Cirsium vulgare. Crystals have been detected in the glandular hairs of Inula viscosa (Werker and Fahn, 1981), I. graveolens (Meric 2009a) and Sigesbeckia jorullensis (Heinrich et al., 2002). Recently, Bárcenas-Argüello et al. (2014) reported that the trichomes of five Cephalocereus species have various crystals shapes, namely prismatic, styloid, and sandy. Additionally, druses have been identified in the anther and stigma trichomes of Helianthus annuus and H. tuberosus by Meric and Dane (2004).

The presence of crystals in floral organs, which are transitory structures, is very noticeable. In vegetative organs, which are long-living structures, crystals provide protection against foraging animals, storage of calcium and oxalic acid, regulate Ca levels in plant tissues and organs, provide tissue strength, are involved in the photosynthetic process, and ensure the detoxification of heavy metals (Franceschi and Horner, 1980; Prychid and Rudall, 1999; MolanoFlores, 2001; Franceschi and Nakata, 2005; Kuo-Huang et al., 2007). Similarly, crystals within floral organs are possibly involved in Ca regulation, protection against herbivores, and provide tissue strength given that floral structures are deprived of supporting tissues (Cote and Gibernau, 2012).

Styloids have been detected in the corollas of 15 species of the Cardueae tribe. However, Jurinea consanguinea, Tyrimnus leucographus, and Xeranthemum annиum had no crystals. Thus, this feature may be presented as a diagnostic character for the Cardueae tribe. Corollas of the Conyza species and Aster squamatus contain druses (Meric, 2008, 2009b), while those in Helianthus annuus and H. tuberosus have styloids and prismatics (Meric and Dane, 2004). No crystals have been observed in the corollas of some of the Inuleae tribe members (Meric, 2009a). The lengths of the styloids in the corollas of the 15 species in which crystals were identified ranged from $7.01 \mu \mathrm{m}$ (Cirsium arvense) to $26.07 \mu \mathrm{m}$ (Centaurea salonitana). The seven species of the subtribe Centaureinae that were investigated had styloids in their corollas, and these crystals were longer than $10 \mu \mathrm{m}$. However, the species of the subtribe Carduinae displayed differences with regard to the styloids in their corollas (absence/presence and measurement). In the species of the subtribe Carduinae, crystals in the corollas were either absent or shorter than $10 \mu \mathrm{m}$.

In the anthers of Cardueae members, the crystals observed are styloids (if present), as in previous studies on Helianthus, Aster, Inula, and Pulicaria (Meric and Dane, 2004; Meric, 2009a, b). Further, in the Cardueae style tissues, the crystals found are styloids (if present), while druses are present in Conyza, Inula, and Pulicaria (Meric, 2008, 2009a,).

The ovaries of Asteraceae members are very remarkable with regards to crystal types. Almost the species of the Cardueae tribe except for Xeranthemum annuum, which has 
styloids, have prismatics in the ovary cells. While prisms have been reported in the ovaries of some species belonging to the Inuleae tribe (Meric, 2009a), styloids have been reported in the ovaries of the genus Conyza (Meric, 2008) pertaining to the Astereae tribe. Additionally, it has been stated that there are no crystals in the ovaries of the studied species of Helianthus, which belongs to the Heliantheae tribe (Meric and Dane, 2004). Further, the ovaries of some taxa of the Cardueae tribe were examined for the presence of crystals by Dormer $(1961,1962)$. The author determined prismatics of different lengths in the ovaries of the Cardueae taxa (Dormer 1961, 1962). The results of the present study agree with Dormer's reports (1961, 1962). All the species investigated had crystals in their ovaries, and the lengths of these crystals ranged from $5.33 \mu \mathrm{m}$ (Tyrimnus leucographus) to $64.35 \mu \mathrm{m}$ (Cirsium vulgare). All the species of the subtribe Centaureinae had prisms shorter than $25 \mu \mathrm{m}$ in their ovaries except for Centaurea diffusa, which had prisms in the ovary cells measuring $27.04 \mu \mathrm{m}$ in length. The subtribe Carduinae exhibited different characteristics with regard to the crystals in their ovaries (in terms of measurement and being prismatic and styloid)

The tribe Cardueae is one of the largest tribes of Asteraceae with about 2,500 species and the earliest classification of this tribe by H. Cassini in 1819 divided it into two subtribes as Carduinae and Centaureinae (Susanna et al., 2006). At the end of the twentieth century, Bremer (1994) divided the tribe Cardueae into the subtribes Echinopsidinae, Carlininae, Carduinae, and Centaureinae. More recently, Susanna et al. (2006) suggested five subtribes for tribe Cardueae according to the nuclear and chloroplast DNA analysis; Carduinae, Carlininae, Echinopinae, Cardopatiinae, and Centaureinae. In this classification, Xeranthemum species have been defined into the subtribe Carduinae as sister to the rest of this subtribe (Susanna et al., 2006). In previous studies Xeranthemит species were included in the subtribe Echinopsidinae after a combined nuclear and chloroplast DNA analysis by Garcia-Jacas et al. (2002), whereas Bremer (1994) classified them as being in the subtribe Carlininae due to their morphological characters. Indeed, in the phenogram (Figure 6), which was constructed based on absence/presence, type, and length of the crystals in the species, $X$. апnиum including the styloids in ovary cells is distinctly separated from the rest of the species of the subtribe Carduinae which has prismatics in its ovary cells. Therefore, for evaluation of the status of $X$. annuum with respect to its crystal patterns, it is also necessary to investigate the species within the subtribes Carlininae, Echinopinae, and Cardopatiinae.

It seems that $\mathrm{CaOx}$ crystal formation is under genetic control and is therefore a constant diagnostic character for plant taxonomy. Thus, it is concluded that the type and location of crystals, especially those in the ovaries and the corollas, can be used as useful data along with morphological and other anatomical characteristics in the taxonomy of the
Cardueae tribe at the species or genus level. Nevertheless, further studies on the nature of $\mathrm{CaOx}$ crystals in Asteraceae are necessary in order to determine the general value of these crystals.

\section{Acknowledgements}

This study was supported by The Scientific Research Fund of Trakya University, Edirne, Turkey [Project No: TUBAP624]. The author would like to thank Prof. Dr. Kerim Alpinar for identification of the materials and the anonymous reviewers for their valuable and constructive comments.

\section{Literature cited}

Bárcenas-Argüello M.L., Terrazas T. and Arias S. 2014. Trichomes with crystals in the Cephalocereus Pfeiff. areoles. Botanical Sciences 92:335-342.

Bremer K. 1994. Asteraceae: Cladistics and Classification. Timber Press, Portland.

Cote G.G. and Gibernau M. 2012. Distribution of calcium oxalate crystals in floral organs of Araceae in relation to pollination strategy. American Journal of Botany 99:1231-1242.

Dane F., Meric C. and Hüseyinova G. 2000. Some ultrastructural observations on calcium oxalate raphide crystal idioblasts and meristematic cells of the adventive root tips of Sternbergia lutea (L.) Ker-Gawl. ex Sprengel (Amaryllidaceae). Turkish Journal of Botany 24:71-80.

Davis P.H. 1975. Tribus Cardueae. In: Davis P.H. Ed. Flora of Turkey and the East Aegean Islands. Vol. 5, pp. 326-623. Edinburgh University Press, Edinburgh.

Dormer K.J. 1961. The crystals in the ovaries of certain Compositae. Annals of Botany 25:241-254.

Dormer K.J. 1962. The taxonomic significance of crystal forms in Centaurea. New Phytologist 61:32-35.

Franceschi V.R. 1989. Calcium oxalate formation is a rapid and reversible process in Lemna minor L. Protoplasma 148:130-137.

Franceschi V.R. and Horner Jr. H.T. 1980. Calcium oxalate crystals in plants. The Botanical Review 46:361-427.

Franceschi V.R. and Nakata P.A. 2005. Calcium oxalate in plants: formation and function. Annual Review of Plant Biology 56:41-71.

Garcia-Jacas N., Garnatje T., Susanna A. and Vilatersama R. 2002. Tribal and subtribal delimitation and phylogeny of the Cardueae (Asteraceae): A combined nuclear and chloroplast DNA analysis. Molecular Phylogenetics and Evolution 22:51-64.

Heinrich G., Pfeifhofer H.W., Stabentheiner E. and Sawidis T. 2002. Glandular hairs of Sigesbeckia jorullensis Kunth (Asteraceae): morphology, histochemistry and composition of essential oil. Annals of Botany 89:459-469.

Horner H.T. 1977. A comparative light- and electron-microscopic study of microsporogenesis in male-fertile and cytoplasmic male-sterile sunflower (Helianthus annuus). American Journal of Botany 64:745-759.

Horner H.T., Kausch A.P. and Wagner B.L. 2000. Ascorbic acid: a precursor of oxalate in crystal idioblasts of Yucca torreyi in liquid root culture. International Journal of Plant Sciences 161:861-868. 
Horner H.T., Wanke S. and Samain M.-S. 2009. Evolution and systematic value of leaf crystal macropatterns: a phylogenetic approach in the genus Peperomia (Piperaceae). International Journal of Plant Sciences 170:343-354.

Horner H.T., Wanke S. and Samain M.-S. 2012. A comparison of leaf crystal macropatterns in the two sister genera Piper and Peperomia (Piperaceae). American Journal of Botany 99:983-997.

Ilarslan H., Palmer R.G. and Horner H.T. 2001. Calcium oxalate crystals in developing seeds of soybean. Annals of Botany 88:243-257.

Kausch A.P. and Horner H.T. 1982. A comparison of calcium oxalate crystals isolated from callus cultures and their explant sources. Scanning Electron Microscopy 1:199-211.

Kausch A.P. and Horner H.T. 1984. Differentiation of raphide crystal idioblasts in isolated root cultures of Yucca torreyi (Agavaceae). Canadian Journal of Botany 62:1474-1484.

Kostman T.A. and Franceschi V.R. 2000. Cell and calcium oxalate crystals growth is coordinated to achieve high-capacity calcium regulation in plants. Protoplasma 214:166-179.

Kuo-Huang L.-L., Ku M.S.B. and Franceschi V.R. 2007. Correlations between calcium oxalate crystals and photosynthetic activities in palisade cells of shade-adapted Peperomia glabella. Botanical Studies 48:155-164.

Lersten N.R. and Horner H.T. 2000. Calcium oxalate crystals types and trends in their distribution patterns in leaves of Prunus (Rosaceae: Prunoideae). Plant Systematics and Evolution 224:83-96.

McAleece N., Gage J.D.G., Lambshead P.J.D. and Paterson G.L.J. 1997. BioDiversity Professional statistics analysis software. Jointly developed by the Scottish Association for Marine Science and the Natural History Museum London.

Meric C. 2008. Calcium oxalate crystals in Conyza canadensis (L.) Cronq. and Conyza bonariensis (L.) Cronq. (Asteraceae: As- tereae). Acta Biologica Szegediensis 52:295-299.

Meric C. 2009a. Calcium oxalate crystals in some species of the tribe Inuleae (Asteraceae). Acta Biologica Cracoviensia - Series Botanica 51:105-110.

Meric C. 2009b. Calcium oxalate crystals in Aster squamatus and Bellis perennis (Asteraceae: Astereae). Phytologia Balcanica 15:255-259.

Meric C. and Dane F. 2004. Calcium oxalate crystals in floral organs of Helianthus annuus L. and H. tuberosus L. (Asteraceae). Acta Biologica Szegediensis 48:19-23.

Molano-Flores B. 2001. Herbivory and calcium concentrations affect calcium oxalate crystal formation in leaves of Sida (Malvaceae). Annals of Botany 88:387-391.

Prychid C.J. and Rudall P.J. 1999. Calcium oxalate crystals in monocotyledons: a review of their structure and systematics. Annals of Botany 84:725-739.

Susanna A., Garcia-Jacas N., Hidalgo O., Vilatersana R. and Garnatje T. 2006. The Cardueae (Compositae) revisited: Insights from its, trnL-trnF, and matK nuclear and chloroplast DNA analysis. Annals of the Missouri Botanical Garden 93:150-171.

Tilton V.R. and Horner Jr. H.T. 1980. Calcium oxalate raphide crystals and crystalliferous idioblasts in the carpels of Ornithogalum caudatum. Annals of Botany 46:533-539.

Volk G.M., Lynch-Holm V.J., Kostman T.A., Goss L.J. and Franceschi V.R. 2002. The role of druse and raphide calcium oxalate crystals in tissue calcium regulation in Pistia stratiotes leaves. Plant Biology 4:34-45.

Werker E. and Fahn A. 1981. Secretory hairs of Inula viscosa (L.) Ait. - development, ultrastructure, and secretion. Botanical $\mathrm{Ga}$ zette 142:461-476.

Yasue T. 1969. Histochemical identification of calcium oxalate. Acta Histochemica et Cytochemica 2:83-95.

Received: September 23rd, 2014

Accepted: January 7th, 2015 